\title{
THE EFFECTIVENESS OF STORY TELLING AND STORY READING METHODS IN TEACHING SPEAKING
}

\author{
A.ST.Aldilah Khaerana \\ STKIP YPUP Makassar \\ khaeranaldilah@gmail.com \\ Nadya Nurhidayah $\mathbf{N}$ \\ STKIP YPUP Makassar \\ nhadhyeannn@gmail.com
}

\begin{abstract}
This research aims to find out the effectiveness of storytelling and story reading methods in teaching speaking. The researchers applied a comparative study method which aims at finding out the comparative effectiveness between the application of storytelling and story reading method in teaching speaking skill. The researchers applied the experimental design that involves two groups; storytelling and story reading method in pretest, treatment and posttest. The subject in this research consisted of the 2nd semester students of Speaking 2 class of STKIP YPUP Makassar. There were two variables in this research, independent and dependent variable. The independent variable was the effectiveness of story reading and storytelling, while the dependent variable included the students' speaking ability. The result shows that there is no method which more effective between storytelling and story reading methods in teaching speaking. This conclusion refers to the overall of the students' speaking achievement score. But based on the speaking categories investigations namely accuracy, fluency and comprehensibility, the storytelling method is more effective in increasing the students' accuracy and fluency in speaking, while the story reading method is more effective in improving the students' comprehensibility.
\end{abstract}

Keywords: Effectiveness, Story Reading, Story Telling, Speaking

\section{A. INTRODUCTION}

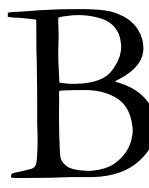

eing as the worldwide language opens a wide range of opportunity for English language to be learned globally around the world. A non-native English learner is firstly recognized to have the capability of good English from the speaking ability.

Speaking is a part of English language skills, as well as the skill in writing, listening, and reading. Many people use it primarily to communicate with other members of their own community or the wider world. Speakingseems intuitively the most important of all the four language skills (listening, speaking, reading, and writing) since people are using language more in utterances (Ur, 1996). In other words, a learner's end product of language learning is to be capable of speaking the target language fluently. In fact, though speaking skill is a crucial part of the language learning process, speaking has often been neglected in the EFL classroom. 
A.ST.Aldilah Khaerana, Nadya Nurhidayah N, The effectiveness of story...

Meanwhile, people sometimes involved in trouble to utter their message by speaking. The problems could be related to themselves, such as the lack of vocabulary, finding hard to arrange a good sentence, or lack of self-confidence to speak up. The other factors are possibly caused by the environment, especially from the educational experiences. Learning in the classroom cannot give adequate information and neither the productive skills which requires more attractive way to deliver the material.

Various techniques can be applied in a speaking class namely conversation, discussion, brainstorming session, storytelling, story reading, directions, interest talk, puppetry, role play, informal debate, meetings, and cooperative learning. Storytelling itself is regarded as a new way of teaching speaking (Bailey and Savage, 1994).

Storytelling and story reading method are the topics of this research. Both are using the story as a media in teaching speaking widely in the classroom. Therefore, we cannot deny the importance of these kinds of techniques and try to find the best way to present and teach it. It then leads on to a question which one is more effective; using storytelling or story reading method in teaching students to speak English.

Therefore, the researchers are interested in conducting in a research about "Comparing the Effectiveness of Story Telling and Story Reading Method in Teaching Speaking."

\section{B. REVIEW OF LITERATURE}

\section{The Concept of Speaking}

As a productive skill, speaking is very essential. One of skill which practically needs a depth understanding rather only pronounce the words. As the interactive process in constructing meaning, speaking skill involves producing and receiving information (Brown in Mariah, 2007)). Moreover, the form and meaning of speaking are dependent on the context in which it occurs, including the participants themselves, their collective experiences, the physical environment, and the purposes for speaking. It is often spontaneous, open-ended, and evolving.

A speaker's skills and speech habits have an impact on the success of any exchange. Speakers must be able to anticipate and then produce the expected patterns of specific discourse situations:

1) Producing the sounds, stress patterns, rhythmic structures, and intonations of the language;

2) Using grammar structures accurately; 
3) Assessing characteristics of the target audience, including shared knowledge or shared points of reference, status and power relations of participants, interest levels, or differences in perspectives;

4) Selecting vocabulary that is understandable and appropriate for the audience, the topic being discussed, and the setting in which the speech act occurs;

5) Applying strategies to enhance comprehensibility, such as emphasizing key words, rephrasing, or checking for listener comprehension;

6) Using gestures or body language

7) Paying attention to the success of the interaction and adjusting components of speech such as vocabulary, rate of speech, and complexity of grammar structures to maximize listener comprehension and involvement (Brown, 1994).

\section{The Concept of StoryTelling}

Story telling has long been a part of our culture, and teachers should recognize its value as a pedagogical tool. While many people believe that telling stories requires substantial efforts and skills, recent experience suggests that anyone interested can learn the art of telling a good tale.

Storytelling is an oral sharing of a personal or traditional story, told using the essence of the tradition from which it originates. As a shared experience between teller and listener, it offers natural language experiences for students.

Storytelling allows students to internalize important aspects of story beginnings and endings, settings, characters, and plot lines. It provides practice in expressing ideas in thought units, using colorful and descriptive language, developing ideas in sequence, and choosing effective action words.

\section{What is Story telling Method}

There are several ways or techniques that we may use to make students actively speak in class, namely: conversing, explaining, interviewing, problem-solving, telephoning, explaining, demonstrating, describing, and telling stories. Story telling itself is regarded as a new way in teaching speaking (Bailey and Savage, 1994).

Pellowski (1990) defined story telling as the entire context of a moment when oral narration of stories in verse or in prose, is performed or led by one person before a live audience. The narration may be spoken, chanted, or sung, with or without musical, pictorial, or other accompaniment. It may be learned from oral, printed or recorded sources. Moreover, story retelling is post reading or post listening recalls in which readers or listeners tell what they remember orally (Morrow, 1989). 
A.ST.Aldilah Khaerana, Nadya Nurhidayah N, The effectiveness of story...

From those definitions, we may specify the story telling in the context of language teaching as the narration of any kind of stories performed by students in front of the class by means of training them to speak in the language they are learning.

\section{Story telling as a Technique in Teaching Speaking}

Iskandar in Mariah (2007:35) listed some techniques or procedures of using story telling in classroom environment, namely: supplied-content story, clued story, endless story, and collaborative story

\section{1) Supplied-Content Story}

The writer names this technique as 'supplied-content' story, since the content of the story that students will tell is provided by teachers. It is the task of teachers to provide stories appropriate to the students. The students' part may be one or two sentences, or even one or two paragraphs. It may vary; depending on the students' ability.

Teachers may provide stories by writing their own stories or modifying the existing ones. It is suggested that in providing the story, teachers take into account the age of the students. Generally, younger children enjoy stories with plot and action. Teenagers like stories with more humor and interplay with characters.

\section{2) Clued Story}

This technique provides some clues for students to tell a story. The clues may be some words, phrases, pictures, or charts. In other words, we have to set the scene of the story. If possible, teachers may include the characters involved in the story when they are providing the clues. The students then follow the frame to do the telling.

Another way of doing clued story is by giving students two or three archetypal characters and having them tell the story by using the characters provided. It is also possible to have students prepare cards with various characters, setting, and plot. The cards, then, are placed in boxes that are labeled "character", "setting", and "plot". After that, we may have students choose a card from each box and make up a story incorporating various ideas (Hamilton and Weiss, 1990)

3) Endless Story

In endless story, the students are free to tell the stories to whatever direction they prefer. The procedure is simple. First, point one of the students to begin his / her story. After that, the student may point out another student to continue the story. At this stage, the student who is pointed out has to begin his story by continuing the previous story told by the first student. After certain extent, he or she may direct the story to whatever he or she wants. Then, it is the turn of another student. 


\section{The Concept of Story Reading}

\section{What is Story Reading Method}

Story reading method is a usual method that almost every student ever applied. Story reading method is a method to gain information by reading the sources then applied in utterances or reading a story aloud or reciting a piece from memory or acting out a drama. (Hamilton and Weis, 2005)

\section{Story Reading as a Technique in Teaching Speaking}

Besides by hearing, children also can obtain a story by reading it. Reading to children should be daily occurrence. This story-sharing time creates far reaching benefits for the children. Some reasons for reading a story are given below:

1) Books extend experiences by telling about other cultures and lifestyles

2) Classics introduce children to fine literature

3) Developing children's oral language skills as they tell their impressions of what is happening using correct sentence structure and appropriate vocabulary

4) Children can work with comprehension skills that they will use later in reading; identifying details, becoming aware of sequence, making inferences, predicting what will happen next, seeing cause-effect relationships, and drawing conclusions.

\section{The Assessment of Oral Test}

\section{Accuracy}

Accuracy is the ability to avoid error in performance, possibly reflecting higher levels of control in the language.

\section{Fluency}

Fluency concerns the learner's capacity to produce language in real time without undue pausing or hesitation. It is likely to rely upon more lexicalized modes of communication, as the pressures of real time speech production are met only by avoiding excessive rule-based computation (Skehan in Parvis, 2008).

\section{Comprehensibility}

Comprehensibility is the utilization of interlanguage structures that are cutting edge, elaborate, and structured (Ellis in Parvis, 2008)

(Adopted from Heaton, 1998: 100) 
A.ST.Aldilah Khaerana, Nadya Nurhidayah N, The effectiveness of story...

\section{RESEARCH METHOD}

\section{Research Design}

The method that the writer applied in this research is thecomparative study. It aimed to investigate the comparison of the effectiveness of the application of storytelling (G1) and story reading method (G2). The researchers applied theexperimental design that involved two groups; storytelling (G1) and story reading method (G2) in pretest (O1), treatment (X) and posttest $(\mathrm{O} 2)$.

\section{Respondents}

The respondents of this research were 76 (seventy six) students of the 2nd semester in STKIP YPUP Makassar. The sampling technique used is cluster random.

\section{Instrument of the Research}

The instrument of this research was the speaking test of the respondents which consist of some stories that were given in pretest and posttest. Pre-test investigated the prior knowledge of the students' speaking ability before the treatment, and the posttest was to measure the students' speaking ability after the treatment. The content of the speaking test was the legendary stories.

\section{Procedures of Collecting Data}

\section{Pre-test}

Before giving the treatment, pre-test was administered to the students. In this part, the researchers introduced themselvesand told their purpose to the student. Then, the students were asked to retold the story about legend that given by the researchers. It was intended to know the prior knowledge of the students' speaking ability. Later the researchers scored the students' speaking ability based on their fluency, accuracy, and comprehensibility.

\section{Treatments}

The treatments were conducted in 4 meetings, which in each meeting, the respondentsere given various legend stories. The steps of treatment in both groups, storytelling and story reading group as follows:

a. Storytelling Group

1. The researchers read a story to the respondents

2. Then, the researchers explained about how to analyze the stories using story outline including the identifications of main characters, settings, problems of the story, story events, and how the problem was solved in the story.

3. The researchers led the students to retell the story in turn.

b. Story reading Group

1. The researchers gave the printed story to the respondents 
2. Then, the researcher explained about how to analyze the stories using story outline including the identifications of main characters, settings, problems of the story, story events, and how the problem was solved in the story.

3. The researchers led the students to retell the story in turn.

\section{Posttest}

Posttest was given after the researchers conducting the treatments. The objective of posttest was to find out whether there was any improvement or not in the respondents' speaking ability.

\section{Data Analysis}

To analyze the research, the researchers employed the following formula:

1. Scoring the students' speaking ability by giving attention on the three competencies: accuracy, fluency, and comprehensibility with scoring system:

a. Accuracy

\begin{tabular}{|c|c|l|}
\hline Classification & Score & \multicolumn{1}{|c|}{ Criterion } \\
\hline Very Good & 5 & $\begin{array}{l}\text { Pronunciation is only very slightly influenced by } \\
\text { the mother tongue. Two or three minor } \\
\text { grammatical and lexical errors }\end{array}$ \\
\hline Good & 4 & $\begin{array}{l}\text { Pronunciation is still moderately influenced by } \\
\text { the mother tongue. A few minor grammatical } \\
\text { and lexical errors but most utterances are } \\
\text { correct }\end{array}$ \\
\hline Average & 3 & $\begin{array}{l}\text { Pronunciation seriously influenced by the } \\
\text { mother tongue but only few serious } \\
\text { phonological errors. Several grammatical and } \\
\text { lexical errors but two or more errors causing } \\
\text { confusion }\end{array}$ \\
\hline Poor & 2 & $\begin{array}{l}\text { Pronunciation s seriously influenced by the } \\
\text { mother tongue with the error causing a } \\
\text { breakdown in communication. Many basic } \\
\text { grammatical and lexical errors }\end{array}$ \\
\hline Very Poor & 1 & $\begin{array}{l}\text { Serious pronunciation errors as well as many } \\
\text { basic grammatical and lexical errors. No } \\
\text { evidence of having mastered any of language } \\
\text { skills. }\end{array}$ \\
\hline
\end{tabular}


A.ST.Aldilah Khaerana, Nadya Nurhidayah N, The effectiveness of story...

b. Fluency

\begin{tabular}{|c|c|l|}
\hline Classification & Score & \multicolumn{1}{|c|}{ Criterion } \\
\hline Very Good & 5 & $\begin{array}{l}\text { Speak without too great effort with wide range of } \\
\text { expression. Searches for word occasionally but } \\
\text { only one or two unnatural pauses. }\end{array}$ \\
\hline Good & 4 & $\begin{array}{l}\text { Has to make an effort at times to search for words. } \\
\text { Nevertheless, smooth delivery on the whole and } \\
\text { only a few unnatural pauses. }\end{array}$ \\
\hline Average & 3 & $\begin{array}{l}\text { Has to make an effort at times and search for } \\
\text { words. There are not many unnatural pauses. } \\
\text { Occasionally halting delivery and fragmentally but } \\
\text { success in conveying the general meaning. }\end{array}$ \\
\hline Poor & 2 & $\begin{array}{l}\text { Long pauses while searches for the desired } \\
\text { meaning frequently fragmentally and halting } \\
\text { delivery. Almost given up making the effort at } \\
\text { times. }\end{array}$ \\
\hline Very Poor & 1 & $\begin{array}{l}\text { Fragmentally delivery. At times gives up making } \\
\text { the effort. }\end{array}$ \\
\hline
\end{tabular}

\section{c. Comprehensibility}

\begin{tabular}{|c|c|l|}
\hline Classification & Score & \multicolumn{1}{|c|}{ Criterion } \\
\hline Very Good & 5 & $\begin{array}{l}\text { Easy for the listener to understand the speakers' } \\
\text { intention and general meaning. Very few } \\
\text { interruption or clarification required. }\end{array}$ \\
\hline Good & 4 & $\begin{array}{l}\text { The speakers' intention and general meaning are } \\
\text { fairly clear. A few interruptions by the listener for } \\
\text { the sake or clarification necessary. }\end{array}$ \\
\hline Average & 3 & $\begin{array}{l}\text { Most of what speakers' say is easy to follow. The } \\
\text { attention is always clear but several interruptions } \\
\text { are necessary to help him to convey the message } \\
\text { or to seek clarification. The speaker make more } \\
\text { complex. or longer sentences }\end{array}$ \\
\hline Poor & 2 & $\begin{array}{l}\text { Only short sentences and phrases can be } \\
\text { understood and then with considerable effort by } \\
\text { someone who is used to listen to the speaker. }\end{array}$ \\
\hline Very Poor & 1 & $\begin{array}{l}\text { Anything of what is aid hardly can be understood; } \\
\text { even when the listener makes a great effort or } \\
\text { interrupt, the speaker is unable to clarify anything } \\
\text { seems to have said. }\end{array}$ \\
\hline
\end{tabular}


(Heaton in Mariah 2007:23)

1. Calculating students' score into 5 level which was based on the standard score of level as follows:

\begin{tabular}{|l|l|l|}
\hline NO. & SCORE & CATEGORY \\
\hline 5 & $91-100$ & Very Good \\
\hline 4 & $76-90$ & Good \\
\hline 3 & $61-75$ & Fair \\
\hline 2 & $51-60$ & Poor \\
\hline 1 & $0-50$ & Very Poor \\
\hline
\end{tabular}

(Depdiknas in Naim,2008)

2. Calculating the mean score of the treatment using the following formulas:

$$
x=\frac{\sum \mathrm{X}}{N}
$$

Where

$$
\begin{array}{lll}
\mathrm{x} & : & \text { Mean Score } \\
\Sigma \mathrm{X} & : & \text { Total of raw score } \\
N & : & \text { The number of students }
\end{array}
$$

(Gay in Mariah,2007)

3. Finding out the Deviation Standard of the students' speaking achievement for those who had been taught using story telling method and who had been taught using story reading method

$$
\mathrm{SD}=\frac{\sqrt{\sum \times 2-\left(\frac{\sum \mathrm{x}}{\mathrm{n}}\right) 2}}{\mathrm{n}-1}
$$

Where:

$$
\begin{aligned}
& \text { SD } \quad \text { The total square of the students' score } \\
& \text { EX : } \quad \text { The total score of the students } \\
& \mathrm{n} \quad \text { The number of students }
\end{aligned}
$$

(Rahman in Astriani 2007:24)

4. Finding out whether or not there was a significant difference between the students' speaking achievement for those who were taught using story telling method and who were taught using story reading method

$$
\mathrm{t}=x=\frac{\mathrm{x} 1-\mathrm{x} 2}{\mathrm{~s}(\mathrm{x} 1-\mathrm{x} 2)}
$$


and

$$
\mathrm{s}(\mathrm{x} 1-\mathrm{x} 2)=\sqrt{ }\left(\mathrm{s} 1^{2} / \mathrm{n} 1\right)+\left(\mathrm{s} 2^{2} / \mathrm{n} 2\right)
$$

Where:

$$
\begin{array}{lll}
\mathrm{t} & = & \text { Test of significance } \\
\mathrm{x} 1 & = & \begin{array}{l}
\text { The mean score of the students' speaking ability will be taught } \\
\text { using story telling method (Group 1) }
\end{array} \\
\mathrm{x} 2 & = & \begin{array}{l}
\text { The mean score of the students' speaking ability will be taught } \\
\text { using story reading method (Group 2) }
\end{array} \\
\mathrm{s} 1 \quad=\quad \begin{array}{l}
\text { The Deviation Standard of the students' speaking ability will be } \\
\text { taught using story telling method (Group 1) }
\end{array} \\
\mathrm{s} 2 \quad=\quad \begin{array}{l}
\text { The Deviation Standard of the students' speaking ability will be } \\
\text { taught using story reading method (Group 2) }
\end{array} \\
\mathrm{n} 1 \quad=\quad \begin{array}{l}
\text { The number of the students who will be taught using story } \\
\text { telling method (Group } 1)
\end{array} \\
\mathrm{n} 2 \quad=\quad \begin{array}{l}
\text { The number of the students who will be taught using story } \\
\text { reading method (Group 2) }
\end{array}
\end{array}
$$

\begin{tabular}{|c|c|c|c|c|c|c|c|c|c|}
\hline \multirow{3}{*}{ Score } & \multirow{3}{*}{ Category } & \multicolumn{4}{|c|}{ Storytelling Group } & \multicolumn{4}{|c|}{ Story reading Group } \\
\hline & & \multicolumn{2}{|c|}{ Pretest } & \multicolumn{2}{|c|}{ Post test } & \multicolumn{2}{|c|}{ Pretest } & \multicolumn{2}{|c|}{ Post test } \\
\hline & & $\mathrm{F}$ & $\%$ & $\mathrm{~F}$ & $\%$ & $\mathrm{~F}$ & $\%$ & $\mathrm{~F}$ & $\%$ \\
\hline $91-100$ & $\begin{array}{l}\text { Very } \\
\text { Good }\end{array}$ & 0 & 0 & 3 & 7.9 & 0 & 0 & 3 & 7.9 \\
\hline $76-90$ & Good & 5 & 13.2 & 11 & 28.9 & 1 & 2.7 & 13 & 34.3 \\
\hline $61-75$ & Fair & 10 & 26.4 & 17 & 44.8 & 13 & 34.3 & 14 & 36.9 \\
\hline $51-60$ & Poor & 22 & 58 & 7 & 18.5 & 21 & 55.3 & 9 & 23.7 \\
\hline $0-50$ & Very Poor & 1 & 2.7 & 0 & 0 & 4 & 10.6 & 0 & 0 \\
\hline
\end{tabular}

(Gay in Mariah, 2007)

\section{FINDINGS \& DISCUSSIONS}

\section{Findings}

The table below shows the comparison between two methods applied in this research namely story reading and storytelling in teaching speaking.

\section{a. Accuracy}

The table above shows the findings on the speaking accuracy which covers the students' speaking performance. This table provides the results of pretest and post test of both groups, storytelling and story reading group.

Table 1.The Respondents' Speaking Accuracy

The table showed that generally the pretest result in storytelling group (G1) and story reading group $(\mathrm{G} 2)$ were still lack. It could be assumed by the result that there was no student whose result was in very good category in both groups. Most students' accuracy in speaking were still in poor category as 22 students (58\%) at the G1 pretest but then on the story reading group there was also the same presentation showed in the number of 21 students $(55.3 \%)$ in 
poor category. In the storytelling group (G1), there were even some students whose skill were still very poor, 1 student (2,7\%) and 4 students (10,6\%) in story reading group (G2). While in the fair category, there were 10 students $(26,4 \%)$ in G1 who achieved this category and only 5 students whose accuracy that could be categorized as good accuracy in the similar group. In the story reading group, there were 13 students $(34,3 \%)$ in the fair category and only 1 student $(2,7 \%)$ in the good category. This leads to conclusion that the students' accuracy in speaking of both group storytelling and story reading are quite poor.The range score between pre-test and post test showed a gradual changing of the result of student's accuracy in storytelling and story reading in the posttest. In the storytelling group, there were 3 students $(7,9 \%)$ whose accuracy in the very good category, while there was no student whose accuracy in the very poor category. The post test of the students in the story telling group in the category of fair and good showed an increase-

\section{b. Fluency}

The table above shows the findings on the speaking fluency which covers the students' speaking performance. This table provides the results of pretest and post test of both groups, storytelling and story reading group.

Table 2 The Respondents' Speaking Fluency

\begin{tabular}{|l|l|c|c|c|c|c|c|c|c|}
\hline \multirow{2}{*}{ Score } & \multirow{2}{*}{ Category } & \multicolumn{4}{|c|}{ Storytelling Group } & \multicolumn{4}{c|}{ Story reading Group } \\
\cline { 3 - 10 } & & \multicolumn{2}{|c|}{ Pretest } & \multicolumn{2}{|c|}{ Post test } & \multicolumn{2}{|c|}{ Pretest } & \multicolumn{2}{|c|}{ Post test } \\
\cline { 3 - 11 } & & F & $\%$ & F & $\%$ & F & $\%$ & F & $\%$ \\
\hline $91-100$ & Very Good & 0 & 0 & 4 & 10.6 & 0 & 0 & 4 & 10.6 \\
\hline $76-90$ & Good & 3 & 7.9 & 8 & 21.1 & 1 & 2.7 & 12 & 31.6 \\
\hline $61-75$ & Fair & 11 & 28.9 & 24 & 63.2 & 10 & 26.3 & 16 & 42.2 \\
\hline $51-60$ & Poor & 22 & 57.9 & 2 & 5.3 & 22 & 57.9 & 7 & 18.5 \\
\hline $0-50$ & Very Poor & 2 & 5.3 & 0 & 0 & 6 & 15.8 & 0 & 0 \\
\hline
\end{tabular}

The pretest regarding fluency in storytelling group (G1) showed that there were $22(57.9 \%)$ students classified into poor score and 2 students (5.3\%) were classified into very poor score. While in the story reading group (G2), 6 students (15.8\%) were classified into very poor score and 22 students $(57.9 \%)$ classified as poor score. From that result, it could be concluded that students' fluency in speaking in the pretest for Group 1 and Group 2 was very poor. 
A.ST.Aldilah Khaerana, Nadya Nurhidayah N, The effectiveness of story...

Nevertheless, after performing the posttest the table above showed that the speaking fluency of both groups hadproved. In G1, the fairness of speaking score stated that 24 students $(63.2 \%)$ were in range score of 61-75 and another side of story reading, even though there were remaining 7 (18.5\%) students in a poor score but 16 students also showed a fairness category as $42.2 \%$ amongst all. It could be concluded that the students were still showing the progress on their storytelling.

\section{c. Comprehensibility}

The table above shows the findings on the speaking comprehensibility which covers the students' speaking performance. This table provides the results of pretest and post test of both groups, storytelling and story reading group.

Table 3 The Respondents' Speaking Comprehensibility

\begin{tabular}{|l|l|c|c|c|c|c|c|c|c|}
\hline \multirow{2}{*}{ Score } & \multirow{2}{*}{ Category } & \multicolumn{4}{|c|}{ Storytelling Group } & \multicolumn{4}{c|}{ Story reading Group } \\
\cline { 3 - 10 } & & \multicolumn{2}{|c|}{ Pretest } & \multicolumn{2}{|c|}{ Post test } & \multicolumn{2}{|c|}{ Pretest } & \multicolumn{2}{|c|}{ Post test } \\
\cline { 3 - 10 } & & $\mathrm{F}$ & $\%$ & $\mathrm{~F}$ & $\%$ & $\mathrm{~F}$ & $\%$ & $\mathrm{~F}$ & $\%$ \\
\hline $91-100$ & Very Good & 0 & 0 & 4 & 10.6 & 0 & 0 & 3 & 7.9 \\
\hline $76-90$ & Good & 1 & 2.7 & 10 & 26.4 & 3 & 7.9 & 25 & 65.8 \\
\hline $61-75$ & Fair & 22 & 57.9 & 22 & 57.9 & 16 & 42.1 & 10 & 26.3 \\
\hline $51-60$ & Poor & 12 & 31.6 & 2 & 5.3 & 17 & 44.7 & 1 & 2.6 \\
\hline $0-50$ & Very Poor & 3 & 7.9 & 0 & 0 & 3 & 7.9 & 0 & 0 \\
\hline
\end{tabular}

The pretest in storytelling group (G1) on the comprehension category of table above showed that $1(2.7 \%)$ out of 38 students who was classified into good category and 22 students $(57.9 \%)$ were classified into fair score. While in the story reading group (G2), 3 students $(2.9 \%)$ were classified into very good score and 16 students $(42,1)$ who were categorized as fair. There were more students whose skill that can be classified as poor, 12 students $(31,6 \%)$ in G1 and 17 students $(44,7 \%)$ in G2. There were 3 students $(7,9 \%)$ who could be categorized having very poor comprehension based on the pretest result in the table above. From that result, it could be concluded that students' comprehensibility in speaking in the pretest for G1 and G2 was quite good.

After performing the treatment, the posttest result showed some significant changing in both groups. There was no students whose post test result that could be categorized as very 
poor ability. It could be seen in the table that in the number of sample who could be classified having good skill in comprehensibility was in $26.4 \%$ or 10 students in G1, meanwhile in the G2 there was $65.8 \%$ of comprehension of 19 students. There was a decreasing in G2 in fair category. The percentage of the pretest result was $42,1 \%$ while in the post test it was only $26,3 \%$. But a quite significant improvement could be seen in good category of this group. There were 25 students $(65,8 \%)$ whose comprehensibility that can be categorized as good. While in G1, there was 1 student who stayed in good category of the pretest result and 10 students whose skill that could be categorized as good in the posttest result. Hence, this could be assumed that story reading group (G2) showed a significant improvement on comprehension rather than storytelling group (G1).

\section{d. Respondents' Speaking Achievement}

The following is the summary of the frequency and percentage score of the student's speaking achievement in the pretest and posttest and for story telling group (G1) and story reading group (G2).

Table 4 The Respondents' Speaking Achievement

\begin{tabular}{|l|l|c|c|c|c|c|c|c|c|}
\hline \multirow{2}{*}{ Score } & \multirow{2}{*}{ Category } & \multicolumn{3}{|c|}{ Storytelling Group } & \multicolumn{3}{c|}{ Story reading Group } \\
\cline { 3 - 10 } & & \multicolumn{2}{|c|}{ Pretest } & \multicolumn{2}{|c|}{ Post test } & \multicolumn{2}{|c|}{ Pretest } & \multicolumn{2}{c|}{ Post test } \\
\cline { 3 - 10 } & & F & $\%$ & F & $\%$ & F & $\%$ & F & $\%$ \\
\hline $91-100$ & Very Good & 0 & 0 & 4 & 10.5 & 0 & 0 & 3 & 7.8 \\
\hline $76-90$ & Good & 0 & 0 & 5 & 13.1 & 0 & 0 & 11 & 28.9 \\
\hline $61-75$ & Fair & 3 & 7.8 & 8 & 21 & 1 & 2.6 & 12 & 31.5 \\
\hline $51-60$ & Poor & 11 & 28.9 & 20 & 52.6 & 15 & 39.4 & 6 & 15.7 \\
\hline $0-50$ & Very Poor & 24 & 63.1 & 1 & 2.6 & 22 & 57.8 & 6 & 15.7 \\
\hline
\end{tabular}

The table above showed there were some students which pretest results that could be categorized as very poor category because their score was less than 50 points. There were 24 students $(63,1 \%)$ in the pretest of story telling group (G1) and 22 students $(57,8 \%)$ in the pretest of story reading group (G2). In the post test score of the similar category, there was a decreasing in the number of students whose post test result in very poor category. There is only 1 student $(2,6 \%)$ in $\mathrm{G} 1$ and 6 students $(15,7 \%)$ in G2 who stayed in this category.

In the poor category of both pretest G1 and G2, there were 11 students $(28,9 \%)$ in G1 and 15 students $(39,4 \%)$ in $\mathrm{G} 2$. The post test of this category, there were 20 students $(52,6 \%)$ of G1 
and 6 students $(15,7 \%)$ in G2. The higher category of poor was fair category. In G1, there were 3 students $(7,8 \%)$ whose pretest result in this category. In the post test of similar group, there was an increasing in the number of students whose post test result in fair category, from 3 students in the pretest into 8 students $(21 \%)$ in the post test. In the second group, there was only 1 student $(2,6 \%)$ whose score that could be categorized as fair in the pretest, while in the post test result there were 12 students $(31,5 \%)$ who reach fair category.

There was no student whose pretest result that could be categorized as good and very good score. This could be found in both groups G1 and G2. In the post test of story telling group (G1), there were 5 students $(13,1 \%)$ whose score that could be categorized as good and 11 students $(28,9 \%)$ in story reading group (G2) in good category. There were 4 students $(10,5 \%)$ in G1 whose post test result that could be classified as very good and 3 students $(7,8 \%)$ in G2 whose score in very good category.

\section{Discussion}

Based on the result of the students' speaking achievement, generally, there is no significant difference between the two methods applied in this research, namely storytelling and story reading method. After applying the methods to improve the students' speaking ability, there is only a slight significance in the students' speaking achievement. It is caused by various variables which integrated into all of the speaking categories; accuracy, fluency and comprehensibility.

Accuracy is the ability to avoid error in performance, possibly reflecting higher levels of control in language. Accuracy in speaking performance covers the students' knowledge of grammar, structures, vocabulary and pronunciation (Mazouzi in Leong and Ahmadi (2017)). The result of pre-test and post test in the story telling (G1) and story reading (G2) groups showed not much improvement in this category. The most common error which found by the researchers was grammatical error when the students delivered the story in their version of their own language based on their comprehension of the story. In retelling the story, the students must use simple past tense in delivering the stories, instead of using simple present tense. The mistake of applying simple past tense which identified was on the using of verb in past form (Verb-2), particularly in the using of irregular verbs. The students mostly generalized all the verbs into regular verbs which change from the present form $(\mathrm{V}-1)$ into past form $(\mathrm{V}-2)$ we just simply add $-e d$ at the end of the verb. It also related to the lack knowledge of the students' vocabulary.

The other aspect which included in accuracy category is pronunciation. It cannot be denied that a second language learner will never have the native speaker's pronunciation, but ignorance toward poor pronunciation can result miscommunication and misunderstanding toward the 
delivered meaning of the utterance. One factor that causes the insignificant result of the students' pretest and post test in the students' speaking accuracy is the lack of students' pronunciation. Poor pronunciation in some sounds particularly vowels such as $[ə]$ and $[\varepsilon]$, is affected by the students' mother tongue in their native language. This error is mostly done by the students who come from Toraja and Flores. The students tend to interchange the pronunciation of these two vowels. In appropriate pronouncing of word 'village' must be [viledz], while the students pronounced this word as [viləd\}]. The other mother tongue influence which identified by the researchers is in the adding of sound [n] such as in the word 'stone'. The students tend to add the sound [n] at the end of the word, therefore the students pronounce the word as [ston] that the correct pronunciation supposed to be [stoun]. This error was mostly conducted by the students who came from Flores and Makassar happens because the people from this areas pronounce every word which ends in [n] sound into [n] sound. It implies that the students' accuracy in pronunciation is affected by their mother tongue. And the least are students who made some pauses "um" or "ers" when the students got lost in finding the words that they wanted to say. This sign indicates that the speaker does not prepare to spend time looking for the vocabulary related to the story given.

There are more students whose ability are improved in the storytelling group (G1) than in story reading group (G2) based on the pretest and post test. The improvement clearly can be identified in the students' pronunciation because in G1 the students heard the story which read by the researchers who use the correct and appropriate pronuciation. Meanwhile, in G2, the students read the story themselves, therefore the students reveal the correct pronunciation based on their prior knowledge about the pronunciation of the words. Thus, in this category, it can be concluded that the storytelling method is more effective in improving the students' speaking accuracy than story reading method.

Accuracy is closely related to fluency in speaking. Since fluency deals with sentence production without any hesitation which indicated from the number of pausing which made by the speakers. Dincer (2012) states that in speaking fluency, grammatical and pronunciation are not very important in speaking. Correction can interrupt a speaker's improvement in speaking. In other words, the knowledge of speaking accuracy could not affect the fluency in speaking. On the contrary, the phenomenon which found by the researchers that accuracy influence the students' fluency in speaking. There were many pauses when the students delivered their stories.. Richard (2008) points out that fluency is the use ofnatural occurring language when the speaker engages and maintain meaningful communication. Fortunately, some of the students 
were still reluctant to produce the words and it cames when the students could not find the word or formulates the sentence which they wanted to say. It can be assumed that the students' prior knowledge of grammar affect their speaking fluency The pretest and post test results showed the improvement of the students' fluency are almost similar to the students' accuracy. It indicates that if the students have an adequate accuracy in speaking, so the students will speak fluently. Therefore, fluency is the extent to which speakers use the language quickly and confidently, with few hesitation or unnatural pauses, false start and word searches. Some of them focused a lot about the characters and the rest about the important event happened in the story. During the treatment, students were introduced to a story outline that led them to facilitate them catching the important points of the story clearly. By using those important points students can reconstruct the story outline effortlessly. When the posttest was given, students could arrange their stories in their own words following the plot better than before. But there also remain those who were very reluctant to produce the words.

The students' comprehensibility can be measured in the way they delivered the stories using their own words and sentences. As Ellis in Parvis (2008) stated that comprehensibility is employing interlanguage structures by taking the important points and descriptions in and reconstruts them in the similar language. After conducting the treatments which delivers-more explanation about the plot and the story outline of the legends, the students' comprehensibility in the story reading (G2) is more improved than the students in storytelling (G2) group. Although the G2 has been provided by the story outline of the legend to facilitate them catching the important points of the story clearly, still they seem distressed in reconstructing the story in their own words. Only short sentences and phrases could be understood from the students' story. The plot was not consistent. Some of them talked a lot about the characters and the rest about the event happened in the story, while the students in G2 retold their stories effortlessly. It is pointed out based on the number of students who gain good category. In the pretest result of G2, there were 3 students in good category. This number increased in the post test result of G2 into 25 students in the same category. It denotes that the students in G2 understood more about the legend which they read themselves than the student who listened tothe story from the storytelling method. Therefore, it can be said that the story reading method is more effective in improving the students' comprehensibility in speaking. Likewise, Isabell, Sobol, Lindauer \& Lowrance, (2004) stated that students in the story reading group improved their language complexity. Furthermore, Snow (1983) stated that story reading benefits children in two ways by providing them with acquisition of language and literacy. Not only do children acquire language and literacy skills, but they also experience vocabulary growth, knowledge of handling 
books, and many other skills. There are numerous research documented between reading stories and their subsequent success on reading readiness task and achievement at school. During the treatment, students were introduced to a story outline that led them to facilitate them catching the important vocabulary in some points of the story clearly. By using those knowledge students can reconstruct the story outline effortlessly. This is supported by Van den Broek \& Espin (2012) thatreading comprehension is a complex interaction among automatic and strategic cognitive processes that enables the reader to create a mental representation of the text. When the posttest was given, students could arrange their stories in their own words following the plot better than previously.

Lastly, for the speaking achievement, it is shown in the table that the final result of students' speaking skills for both groups was different. The score was improved from very poor to poor score for Group 1. It was proved by the increasing of mean score where in the pretest were low in range 49.6 categorize as poor and in the posttest has a slight improvement in 52.8 points. The score category for Group 2 was changed a little. The mean score for the pretest were 46.4 and for the posttest were 69.8. In the other word, the total score for Group 2 was changed inconsiderable because both were in the range of poor score. It could be underlined that there was no difference between the students' speaking skills in the pretest for both groups. It then impacted their result in posttest. That is to say, the significant differences in result happened because both group actually had different ability in speaking tended to ascend after the treatment, and it was more effective to use story reading method in teaching students' to speak. Based on the data analysis above, it could be seen that the raise of students' ability of accuracy, fluency, and comprehensibility showed a significant increase when story reading method was applied.

\section{E. CONCLUSION}

Depending on the elaboration above, in conclusion, there is no method which more effective between storytelling and story reading methods in teaching speaking. This conclusion refers to the overall of the students' speaking achievement score. But based on the speaking categories investigations namely accuracy, fluency and comprehensibility, the storytelling method is more effective in increasing the students' accuracy and fluency in speaking.In the other side, the story reading method is more effective in improving the students' comprehensibility. This can be said that, by knowing that some students enjoy reading method for engaging their comprehension, teachers or lecturers will be more helpful in preparing the materials for their classroom activities rather than any direct presentation. 


\section{REFERENCES}

Aiex, N. K. (1998). Storytelling : Its wide-Ranging Impact in the Classroom. [ED: 299 574]. Alvey, R.G. (1974). The Historical Development of Organized Storytelling to Children in the United States. Phd Dissertation, University of Pennsylvania.

Bailey, K.M., \& Savage, L. (1994). "New ways in teaching speaking." Alexandria, VA: Teachers of English to Speakers of Other Languages.

Brown. (1994). Teaching by principle. San Fransisco: San Fransisco State University.

Chuang, Y. (2009). Foreign language speaking assessment: Taiwanese college English teachers' scoring performance in the bolistic and analytic rating methods. Retrieved on March 4, 2009, from http://iteslj.org/

Cunningham, M. (1996). Speaking skills. Washington DC: National Clearinghouse for ESL Literacy Education.

Dincer, Ali. (2012) Promoting Speaking Accuracy and Fluency in Foreign Language Classroom: A Closer Look at English Speaking Classrooms. An Article. https://www.researchgate.net/publication/319925468. Retrieved on 25 June 2018

Ed, Sask. (2009). Speaking and listening activities. Retrieved on February 25, 2009, from http://www.sasked.gov.sk.ca/docs/mla/assessform.pdf/

Eric, (2006). Using story telling to teach oral communication competencies. Retrieved on February 20, 2006, from http://www.ericdigests.org/

Hamilton, M \& Weiss, M. (2005). Children Tell Stories: Teaching and Using Storytelling in the Classroom. Online Article. New York: Owen Publishers, Inc. Retrieved on on March 15, 2015 from https://www.rcowen.com/PDFs

Hartman, (2009). Jed. Jed's guide to story reading.Retrieved on February 25,2009, from http://www.kith.org/logos/things/reading/html\#schedule

Heaton, J.B. (1987). Language Testing, San Fransisco: Longman

Isabell, R., Sobol, J., et al. (2014) The Effects of Storytelling and Story Reading on the Oral Language Complexity and Story Comprehension of Young Children, Dec, Volume 32, Issue 3, 157-163. Springer. Early children education Journal

Jianing, X. (2009). Story telling in the EFL speaking classroom. Retrieved on February 14,2009, from http://iteslj.org/

Leong, Dani. (2009)Once upon a time:using story telling activities in the esl/ efl classroom. Retrieved on February 17. http://www.storyconnection.net/?content=games

Leong, Lai-Mei \& Ahmadi, Seyedeh M. (2017) An Analysis of Factors Influencing Learners' English Speakin/g Skill. International Journal of Research in English Education. 34-41 Ijreeonline.com. Retrieved on 5th July 2018

Mariah. (2007). Improving students' speaking ability through story telling. Thesis, Makassar: State University of Makassar.

Parvis (2008). The teacher as moderator: a technique for interactional learning. ELT Journal 37, 3: 221-228.

Rasyidah .(1995). Group work in teaching speaking. Thesis, Makassar: State University of Makassar.

Richards, Jack.C. (2008). Teaching Listening and Speaking from Theory to Practice. Cambridge University Press. New York. 
Volume 4, Number 2, December 2018

Snow, C.E. (1983). Literacy and language:Relationships during the preschool years. Harvard Educational Review,53(2) ,165-187.

Snow, C.E. (2001). Knowing What We Know: Children, Teachers, Researchers. Educational Researcher, 30(7), 3-9.

Sulaiman, I. (2009). The utilization of story telling as a technique in teaching speaking. Online Article. Retrieved on February 26, 2009, from http://www.co.cc

Van den Broek, P., \& Espin, C. A. (2012). Connecting cognitive theory and assessment: Measuring individual differences in reading comprehension. School Psychology Review, 41(3), 315-325.

Yu, L. (2009). Story telling for enriching EFL HS. classes. Retrieved on March 15, 2009, form http://iteslj.org/ 